\title{
A Study of the Teaching Management Models under Credit Unit System in China
}

\author{
Yiquan Hong ${ }^{1}$ \\ ${ }^{1}$ Zhejiang University City College, \\ Hangzhou, China
}

\author{
Jiming Li $^{1^{*}}$ \\ ${ }^{1}$ Zhejiang University City College, \\ Hangzhou, China \\ ${ }^{*}$ Corresponding author
}

\author{
Xin Tong ${ }^{1}$ \\ ${ }^{1}$ Zhejiang University City College, \\ Hangzhou, China
}

\begin{abstract}
With the reform of the higher education system in China in recent years, the teaching management model of the higher education attracts more and more attention. Implementing the reform con-cerning credit unit system in Universities, developing a multi-skill, all-round development of talents, which has become an inevitable tendency in the development of Chinese higher education. In the paper, according to the present situation of teaching management models under the credit unit system, the existing problems of teaching management models are studied, and some solutions are analyzed. In the end, the author provides some suggestions for the further development and reform of teaching management models under the credit unit system in China.
\end{abstract}

Keywords: credit unit system; teaching management model; institutions at tertiary level

\section{Introduction}

Along with the deepening of China's reform and development of the higher education, the internal management system reform, especially the reform of teaching management model has attracted more and more attention in society. The teaching management model refers to achieve the teaching goal, the operation of the teaching work, teaching operation rules and characteristics of abstract or theoretical generalization, to reveal the essential attribute of teaching management. Currently, teaching management in the presence exits many drawbacks, such as excessive teaching plan, the single training mode, we should take the flexible educational system measures to solve it. Under the premise of maintaining the necessary unity, students can adapt to different situations to arrange teaching and learning requirements, which will help to improve overall quality of students.
The credit unit system is used to select a curriculum as the core, the guidance of teachers as auxiliary, through Grade Point Average and credits, to measure the overall quality and quantity of student learning by the teaching management system. The implementation and improvement of credit system are both in the United States also. It reflects the idea of student-centered, respect for individual differences, focus on personality development and advanced educational concepts. The credit system is elective as a prerequisite, to credit as a learning measurement unit, to obtain the necessary minimum credits as a graduate and get a degree in teaching management system. The credit unit system originated in the late eighteenth Century German elective system. The bud to carry out credit unit system in China can be traced back to 1918 seeds, when he was headmaster of Peking University, Cai Yuanpei implementation of the elective system. There have been few colleges and universities carrying out the complete credit system in China, most colleges and universities are used the scholastic year system. In this paper, according to the present situation of teaching management model of credit system, research on the existing problems of credit system teaching management mode, explore solutions to the problem, can provide some suggestions for the reform and development of credit unit system management mode.

\section{Analysis of the present situation of teaching management model of the credit unit system}

Universities and colleges are no longer arranged fix courses and learning time for students according to major. Students can free to arrange their own courses, the instructors and class time according to their interests. It can stimulate students' initiative and positive, clear the direction of their own learning, rational planning for the future and direction of development.

Under the credit unit system, students can graduate in obtaining the minimum total credits. Students owning 
stronger learning ability can arrange compactly their own learning time and select lots of courses as much as possible, so that they can acquire required credits and will graduate in advance. Students owning weaker learning ability can extend the school system and delay graduation according to take a make-up examination or retake a course after failing to pass examination. Credit unit system in the management system of student status, academic planning and other aspects become more flexible, so that students can make a study plan to meet their own need, choose learning contents and learning methods. This flexible education system is not only to fully respect the individual differences of students, but also to create conditions for students' entrepreneurial experience.

\subsection{Promoting the renewal of teaching management models and instruments}

In order to meet the need of the students, many colleges and universities launched dual degrees, minor degrees, the tutor system and other management models. Double degree and minor degree to meet the strong learning ability of students who want to learn other specialized professional knowledge demand. The Tutorial System is that students are free to choose tutors according to tutors' personal circumstances and class atmosphere, to guide students to select courses, learn and complete theses. Tutors can help students understand the training objectives, make learning plans, understand the student's progress and learning situation, and give students advice and help. At the same time, educational management departments in colleges and universities use computer system to carry out the design and management of elective system and count credits and goals. It improves the efficiency of teaching management.

\subsection{Meeting the need of the students}

The credit unit system aims to obtain credit through the examination. Examination qualified students can obtain corresponding credits, but not qualified students for the exam by extending their learning time, until they pass all the exams. Students only need the minimum graduation credits to graduate. In addition, students can choose the future employment-related elective courses to improve their professional skills and practical ability. School need to adjust the professional setting according to the needs of the market, also can set curriculum to meet market needs. Students can choose and future employment, entrepreneurship related courses, the entrepreneurship education in independent into education system, through to the teaching plan, curriculum setting, teaching practice and going.

\subsection{Encouraging teachers to improve their teaching level}

After the realization of self-selection, students can choose their favorite courses and teachers which they love her teaching ways according to the evaluation and suggestions of students. The number of students will affect the course of opening. If the number of students in the course does not reach a certain amount, the teacher of the course will be canceled automatically. In universities, the number of course selection can be used as criteria for evaluating teachers. It can encourage teachers to learn and update teaching content, enhance teachers' sense of competition, mobilize the enthusiasm of teachers, improve their teaching level and adjust teaching methods to attract students.

\subsection{Reform of curriculum system, teaching contents and teaching methods}

Although carrying out the credit unit system in colleges and universities gives students full freedom, there is still flexibility. Schools can stipulate specialized courses such as required courses, but also can increase elective courses. To make all students acquire credits, then graduate seamlessly and develop lots of high-quality talents which can serve the community, school need to distribute reasonably the entire curriculum system according to the characteristics of the professional courses and take full account of the needs of society. Students own the autonomy of selecting courses. To attract more students to choose this course, teachers should change the past mode of teaching, then increase teaching flash point.

\section{Contradictions and problems faced by the credit unit system teaching model}

Throughout China's implementation of credit unit system in Colleges and universities, most did not jump out the framework of academic year system. In the path of the implementation of credit system, all curriculums are divided into compulsory courses, elective courses, elective courses and practice courses, and it provides credit value about students' degradation and dropping out of school. With the gradual construction and improvement of the market economic system, China's higher education with international standards to speed up the pace, in this context, the school year credit system has exposed to different extent some contradictions and issues that must be resolved to deepen reform and research.

\subsection{The contradiction between teaching management mechanism and credit system}

The basic form of the current higher education in China is a professional education in universities; it highlights its rigid features in teaching management. The examination and 
teaching management regulations in most colleges and universities are very strict and specific, and the basic characteristics of flexible teaching management of credit system is: teaching plan, curriculum system, the professional choice and learning time are flexible. The elastic characteristic of credit system requires that the current teaching management mechanism must be reformed. China's current teaching management system is dominated by the planning mechanism, and it operates in accordance with the unified neat rhythm. But credit unit system is based on the core of the operating mechanism selection, which leads to the contradictions between teaching management mechanism and credit system.

\subsection{The contradiction between teaching management mechanism and the credit unit system}

The current teaching management model is top-down configuration of teaching resources, and it owns a strong administrative color. Allocation of resources is based on different types of colleges and universities in accordance with the plan prepared with human, financial, material, basically the system can do both domains, resources dynamic balance, easy to unified management. But this allocation of resources easily lead to fragmentation, resources cannot be shared. It is inconsistent with the mechanism of complete credit system, and can hinder the sharing of educational resources among intercollegiate.

\subsection{The contradiction between teaching management organization and the credit unit system}

Compared with the traditional academic year system, credit unit system is divided into the elective courses, accumulated points system, main and auxiliary repair system, tutorial system and other management system, of course constitution of students in a class has changed greatly. In order to strengthen the monitoring of students' academic, educational administration personnel should be familiar with the policy about credit unit system and change the traditional concept of educational work. They need to use expertly the teaching management system, master each course and convey timely teaching information to make each teaching arrangements. They also are good at communicating with students and instructors and answering questions. At the same time, most colleges and universities also carry out the Academic Early Warning System. To strengthen the management of student, when graduation examination graduating students must not only statistic, but also consider the early graduation of students. These managers having the ability to work has put forward higher requirements.

\section{Measures about perfecting the teaching management model of credit unit system}

\subsection{Guide students to understand training plan}

Early into the university, schools should arrange professional person in charge of the majors professional training knowledge related explanations, including the employment direction of the professional future, prospects for the future, as well as in the university need to learn professional knowledge and relevant curriculum, so that students in-depth understanding of their professional, reasonable arrangements for study schedule. Prior to selecting courses, schools can arrange for teachers to give students some suggestions about courses. Schools can also be arranged in the previous two years given default courses, students can increase, decrease, or change courses according to their needs. At the same time, the curriculum teaching management departments should strictly. Commencement of the course content and teachers qualified to make specific provisions regulate the curriculum, reasonable arrangements for the course.

\subsection{Perfecting the elective system to improve the teaching quality}

Managers need to learn to use modern management tools, which is used in teaching modern management practices. What's more, schools can establish an electronic management platform to the teaching process management, student achievement management, and social practice management as the main content, so as to realize the network teaching management and digital. Schools should improve the system where to select courses and regularly update system. Meanwhile, schools also provide sufficient courses for students to select. Perfecting teaching quality supervision and evaluation, which is the key to effectively managing scientific teaching. First of all, schools should improve the teaching quality supervision system to quantify the evaluation criteria, arouse the enthusiasm of the teachers, develop teaching management standards, as well as the supervision and assessment mechanism. Secondly, schools must continue to improve the mechanism of competition, enhance teachers' initiative. Thirdly, they also build a superior incentive, to give more opportunities to those outstanding teachers.

\section{Conclusion}

The credit unit system gives students a full freedom, but the freedom is not laissez-faire, so universities an colleges should develop a strict and flexible learning management system, giving students full development space, and fully mobilizing students to participate in teaching activities of the initiative and enthusiasm. However, colleges also need to guide teachers, so that they play a leading role in the 
students, to restrain and protect student achievement and eliminate the phenomenon of learning to relax. Teachers should adopt different ways to carry out regular attendance, and open enough room to let students to learn. Therefore, teachers can advocate students to study in the self-study hall or the library to learn and ensure adequate learning space and time.

\section{References}

[1] Ni Ding, "Research on the teaching management mode of two level colleges," Serial, Science and Tech-nology Innovation Herald, pp. 1-2, 2012

[2] Yunlan Wu, "Research on the pro-blems and Countermeasures in the reform of credit system in
Colleges and universities Chinese," Diss, Shanghai Jiao Tong University, pp. 17-62, 2008

[3] Yanyan Zhu, "Research and im-provement of the status quo of newly built undergraduate course colleges and universities teaching management of credit system," Diss, East China Normal University, pp. 60-65, 2008

[4] Yan Zhao, "Research on theory and practice of the reform of college teaching management," Serial, Education Forum, pp. 17-18, 2014

[5] Chunfu Yang, "Thinking of college teaching management," Diss, Science \& Technology Vision, pp. $150-152,2014$

[6] Wen Wei, "Research on teaching management of credit system of new private universities and colleges of undergraduate course" Diss, Edu-cation Forum, pp. 4560,2013 